\title{
Field studies of a technique to mitigate ground settlement of operating highways*
}

\author{
Yue-dong WU ${ }^{1,2}$, Hong-guo DIAO ${ }^{\dagger 1,2}$, Jian LIU ${ }^{3}$, Chui-chang ZENG ${ }^{1,2}$ \\ $\left({ }^{1}\right.$ Key Laboratory of Ministry of Education for Geomechanics and Embankment Engineering, Hohai University, Nanjing 210098 , China) \\ ( ${ }^{2}$ Jiangsu Research Center for Geotechnical Engineering Technology, Hohai University, Nanjing 210098, China) \\ ( ${ }^{3}$ Shenzhen Graduate School, Harbin Institute of Technology, Shenzhen 518055, China) \\ ${ }^{\dagger}$ E-mail: hhudiao@163.com \\ Received Mar. 11, 2016; Revision accepted June 8, 2016; Crosschecked June 14, 2016
}

\begin{abstract}
In the eastern coastal region of China, many operating highways built over soft ground are vulnerable to severe post-construction settlement. In this study, a technique using jet grouted piles is developed to mitigate post-construction settlement. The piles are installed by drilling boreholes throughout the embankment. The principal stages of the construction process are described, and two field tests in China, on the Lianyan and Linhai highways, are presented. The results revealed that ground heaves of up to $219 \mathrm{~mm}$ and $337 \mathrm{~mm}$ induced during a short construction period were able to mitigate the settlement of the embankment. The average settling rate was significantly reduced from $60 \mathrm{~mm} / \mathrm{y}$ to $9 \mathrm{~mm} / \mathrm{y}$ on the Lianyan highway. Lateral ground displacement on the Linhai highway increased with time during construction, but after construction showed a slight reduction associated with the dissipation of excess pore water pressure. An analytical method was adopted to describe the ground heave due to the jet grouted piles. The ground heave increased with grout pump pressure, but decreased as the embankment load and distance from the pile center increased.
\end{abstract}

Key words: Operating highway, Post-construction settlement, Jet grouted pile, Ground heave http://dx.doi.org/10.1631/jzus.A1600231

CLC number: TU473.1

\section{Introduction}

The rapid construction of highways in China has brought a series of geotechnical problems, especially for those built over soft ground in the eastern coastal region. One major problem associated with road embankment is long-term settlement (Zhou et al., 2012; Ye et al., 2013; Liu et al., 2015). If not ad-

\footnotetext{
${ }^{\ddagger}$ Corresponding author

* Project supported by the National Natural Science Foundation of China (Nos. 51279049 and 5141001028), the Program for Changjiang Scholars and Innovative Research Team in University (No. IRT15R17), and the Fundamental Research Funds for the Central Universities (No. 2014B04914), China

(DD ORCID: Yue-dong WU, http://orcid.org/0000-0003-2901-5882; Hong-guo DIAO, http://orcid.org/0000-0002-1486-9757

CC Zhejiang University and Springer-Verlag Berlin Heidelberg 2016
}

dressed properly, severe post-construction settlement will tend to yield serious consequences for the maintenance of the road pavement. In recent decades, more emphasis has been put on investigations of ground improvement techniques applied before construction. Various traditional ground improvement techniques have been widely applied to overcome poor ground conditions, including dynamic compaction (Mayne et al., 1984; Hanna and Yulek, 2014), grouting (Yoshitake et al., 2004; Modoni and Bzówka, 2012), rigid piles or flexible columns (Poulos, 2007; Shahu and Reddy, 2011), and preloading with or without prefabricated vertical drains (Chu et al., 2000; Saowapakpiboon et al., 2011). More recently, some new techniques have also been developed, including biogrouting using microorganisms (van Paassen et al., 2010) and grouted gravel columns (Liu 
et al., 2015). In view of the large amount of literature on ground improvement, Schaefer et al. (2012) summarized and classified the techniques. They listed seven main categories including densification, consolidation, load reduction, reinforcement, chemical treatment, thermal stabilization, and biotechnical stabilization.

Nevertheless, studies of how to mitigate severe post-construction ground settlement are relatively rare. The current popular method is to pave a new asphalt layer over the old pavement. Although this method can avoid excavating the embankment, it is not an ideal solution as the additional load imposed on the subgrade can often increase settlement. In this study, a practical technique using jet grouted piles installed by drilling boreholes throughout the embankment was developed to support the embankment and to alleviate the post-construction settlement of operating highways. The principal stages of construction are described and two case studies on the use of the technique are reported, including the Lianyan and Linhai highways in China. Both cases were instrumented and measured to investigate the performance of the embankment. A theoretical method proposed by $\mathrm{Wu}$ et al. (2016) was also adopted to analyze the short-term heave due to jet grouting.

\section{Principal stages of construction}

Since jet grouting was developed in Japan in the 1970 s, it has become one of the most widely used ground improvement techniques (Poh and Wong, 2001; Yoshitake et al., 2004; Flora et al., 2013; Wang et al., 2013). A high-velocity jet that breaks down the soil structure and mixes it with grout slurry to create a reinforced "soilcrete" body is used to improve the mechanical properties of soil. Compared with other techniques, jet grouting has obvious advantages in that it can be used in almost any type of soil, and various diameter piles can be rapidly created using relatively light equipment and adjustable operating parameters. Inspired by these characteristics, we applied jet grouting to mitigate ground settlement in operating highways.

Typical cross-sections of the principal construction stages for the proposed technique are illustrated in Fig. 1. Construction is carried out on one side while the other side keeps operating. The detailed construction process consists of the following steps:

1. Boreholes are drilled and cleared throughout the whole embankment following a predetermined vertical orientation (Fig. 1a). The borehole diameter ranges from 80 to $100 \mathrm{~mm}$. This can protect the original asphalt pavement and prepare for subsequent installation.

2. Jet grouting is performed in each borehole using grouting equipment comprising a fixed grout production plant. A small diameter hole is drilled with a jet rod and drill bit down to the required depth. Grout with a certain water-cement ratio is injected at high pressure into the soil from several jet nozzles situated horizontally just above the bottom of the drill bit. Then, the rod and drill bit are kept rotating and jetting while being slowly withdrawn up to the bottom of the embankment. Thus, a jet grouted pile with a cylindrical body is produced consisting of injected grout and displaced soil particles (Fig. 1b).

3. The boreholes in the embankment are backfilled and compacted with medium-coarse sand, cement concrete, and asphalt sequentially to recover the road pavement for transportation (Fig. 1c). The same construction is then applied on the other side of the highway until the whole embankment is supported by jet grouted piles (Fig. 1d).

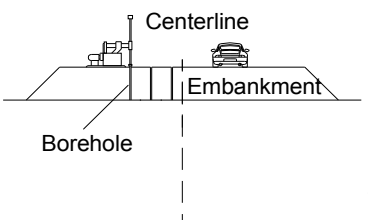

(a)

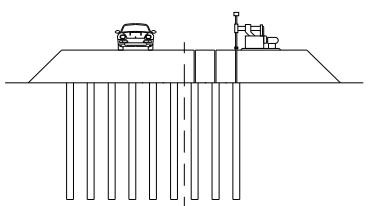

(c)

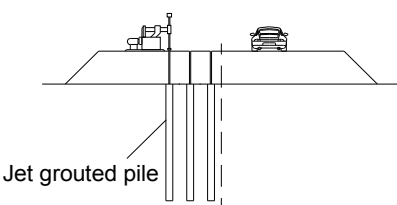

(b)

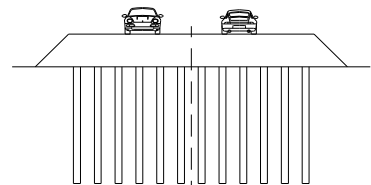

(d)
Fig. 1 Illustration of the principal stages in the construction of jet grouted piles

The materials used in the technique, water and cement, are natural and inert, and have no negative influence on the surrounding environment. The 
design pile length is slightly longer than the depth of soft soil to be improved. The pile spacing is usually 2 to 3 times the pile diameter in clayey soil, as suggested by Chang and Zhang (2007). Furthermore, in-situ trial piles should be constructed to demonstrate whether the specified piles can be achieved using the design operation parameters (grout pump pressure, withdrawal rate, and rotation speed of the jet bit). All operation parameters should be monitored and controlled strictly to ensure the quality of construction. The quality of the piles can also be checked by taking core samples.

\section{Field studies}

\subsection{Field case of the Lianyan highway}

The Lianyan highway field trial was located in the eastern coastal area of Lianyungang, China. High water content, high compressibility, low shear strength, and low ground bearing capacity are characteristics typical of Lianyungang soft soil (Deng et al., 2014). However, ground improvement before construction was not addressed adequately, resulting in excessive post-construction settlement induced by the static and dynamic load of the busy highway. The initial response was to pave a new asphalt pavement over the old one every year. It was recorded that an extra 48 , 55,70 , and $60 \mathrm{~mm}$ thickness of new asphalt was paved in 2008, 2009, 2010, and 2011, respectively. The total thickness increased from $180 \mathrm{~mm}$ in 2006 to $413 \mathrm{~mm}$ in 2013. However, additional pressure imposed on the subsoil by the extra asphalt contributed to even more settlement. Another non-negligible factor associated with rapid economic development in China was that the traffic volume kept growing. A rough survey indicated that the average traffic volume per day in 2013 was about $30 \%$ higher than that in 2006, meaning that the vehicle load imposed on the subsoil was greater than ever before.
A typical soil profile obtained from the borehole logs is shown in Fig. 2. There is a 2.8-m thick fill layer underneath the embankment. Below it is a clay layer with a thickness of $11.0 \mathrm{~m}$. A thick silty clay lies underneath but is not penetrated. According to the unified soil classification system, these three types of soil from top to bottom can be classified as low-plasticity clay (CL), high-plasticity clay $(\mathrm{CH})$, and CL, respectively (ASTM, 2011). The main soil properties at this site are listed in Table 1. The average water content of the clay layer is about $45.5 \%$ and close to the liquid limit, indicating its high plasticity. The total unit weight varies from $17.5 \mathrm{kN} / \mathrm{m}^{3}$ in the clay to $18.8 \mathrm{kN} / \mathrm{m}^{3}$ in the silty clay. The void ratio ranges from 0.92 to 1.20 . According to $1 \mathrm{D}$ consolidation tests, the constrained modulus of the clay is generally small with a value of $2.59 \mathrm{MPa}$. The undrained shear strength of the soil obtained by field vane shear tests (VSTs) is also given in Table 1. The shear strength increases with depth, except in the fill layer.

A cross-sectional and a plan view of the experimental highway with a three-lane dual carriageway are shown in Figs. 2 and 3, respectively. The total length of the trial site was $30 \mathrm{~m}$ and the test

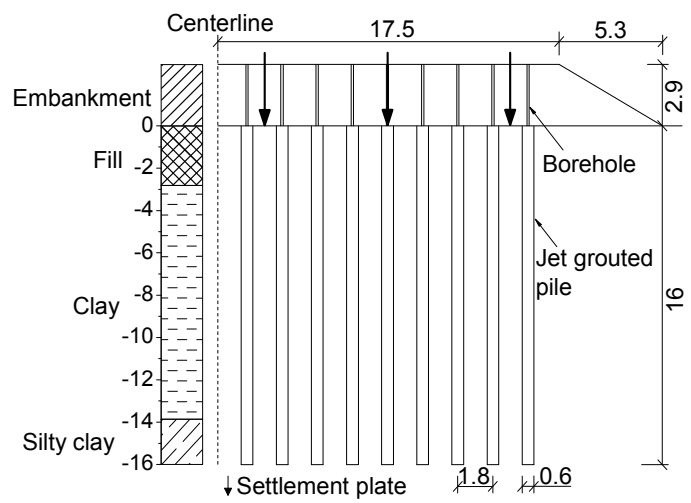

Fig. 2 Cross-section of the experimental site on the Lianyan highway (unit: $\mathrm{m}$ )

Table 1 Main soil properties of the Lianyan highway

\begin{tabular}{cccccccc}
\hline $\begin{array}{c}\text { Soil } \\
\text { profile }\end{array}$ & $\begin{array}{c}\text { Water } \\
\text { content, } w \\
(\%)\end{array}$ & $\begin{array}{c}\text { Liquid } \\
\text { limit, } w_{\mathrm{L}} \\
(\%)\end{array}$ & $\begin{array}{c}\text { Plastic } \\
\text { limit, } w_{\mathrm{P}} \\
(\%)\end{array}$ & $\begin{array}{c}\text { Void ratio, } \\
e\end{array}$ & $\begin{array}{c}\text { Total unit } \\
\text { weight, } \gamma \\
\left(\mathrm{kN} / \mathrm{m}^{3}\right)\end{array}$ & $\begin{array}{c}\text { Constrained } \\
\text { modulus, } E_{\mathrm{s}} \\
(\mathrm{MPa})\end{array}$ & $\begin{array}{c}\text { Undrained } \\
\text { shear strength, } \\
c_{\mathrm{u}}(\mathrm{kPa})\end{array}$ \\
\hline Fill & 32.0 & 41.6 & 22.4 & 0.95 & 17.9 & 2.63 & 14.9 \\
Clay & 45.5 & 52.5 & 26.7 & 1.20 & 17.5 & 2.59 & 13.1 \\
Silty clay & 35.2 & 43.7 & 22.0 & 0.92 & 18.8 & 3.60 & 18.8 \\
\hline
\end{tabular}


embankment was $2.9 \mathrm{~m}$ high, with a crown width of $35 \mathrm{~m}$. A total of 306 jet grouted piles arranged in a square pattern with a center to center spacing of $1.8 \mathrm{~m}$ were installed in the direction of the arrows shown in Fig. 3. Each jet grouted pile had a diameter of $0.6 \mathrm{~m}$ and was formed using grout slurry, consisting of water and Portland cement with a compressive strength of $42.5 \mathrm{MPa}$ after $28 \mathrm{~d}$ of curing. The jet grouted pile was $16 \mathrm{~m}$ long with the pile tip reaching the silty clay. Construction on the left side preceded that on the right side to ensure that transportation was not blocked completely. Note that the initial installation sequence on the left side was in the transverse direction. To minimize the adverse effects of the second pile installation on the first, the sequence of the second installation was turned to be in the longitudinal direction.

The response of the embankment to jet grouting was measured by instrumentation (Fig. 3). Nine settlement plates (L1-L9 and R1-R9) were embedded at the bottom of the embankment on each side. L1-L3 and R1-R3 were placed near the left and right shoulders of the embankment, respectively. L4-L6 and R4-R6 were located at the center of each side, whereas L7-L9 and R7-R9 were installed close to the centerline of the embankment. All settlement plates were measured using a level instrument with a standard deviation of $\pm 0.5 \mathrm{~mm}$ for $1 \mathrm{~km}$ double run leveling. The jet-grouting parameters used during a 50-d construction period at this site are listed in Table 2. Quality was assessed via unconfined compression tests in the laboratory using core samples (Fig. 3). The average unconfined compression strength measured was about $0.44 \mathrm{MPa}$.

Table 2 Jet-grouting parameters used on the Lianyan highway

\begin{tabular}{lc}
\hline \multicolumn{1}{c}{ Parameter } & Value \\
\hline Number of nozzles & 2 \\
Nozzle diameter $(\mathrm{mm})$ & 2.0 \\
Grout pump pressure $(\mathrm{MPa})$ & 20 \\
Grout mix (water cement ratio, in mass) & $1: 1$ \\
Grout specific gravity & 1.5 \\
Drilling rod rotation rate $(\mathrm{r} / \mathrm{min})$ & 18 \\
Withdrawal rate $(\mathrm{m} / \mathrm{min})$ & 0.2 \\
\hline
\end{tabular}

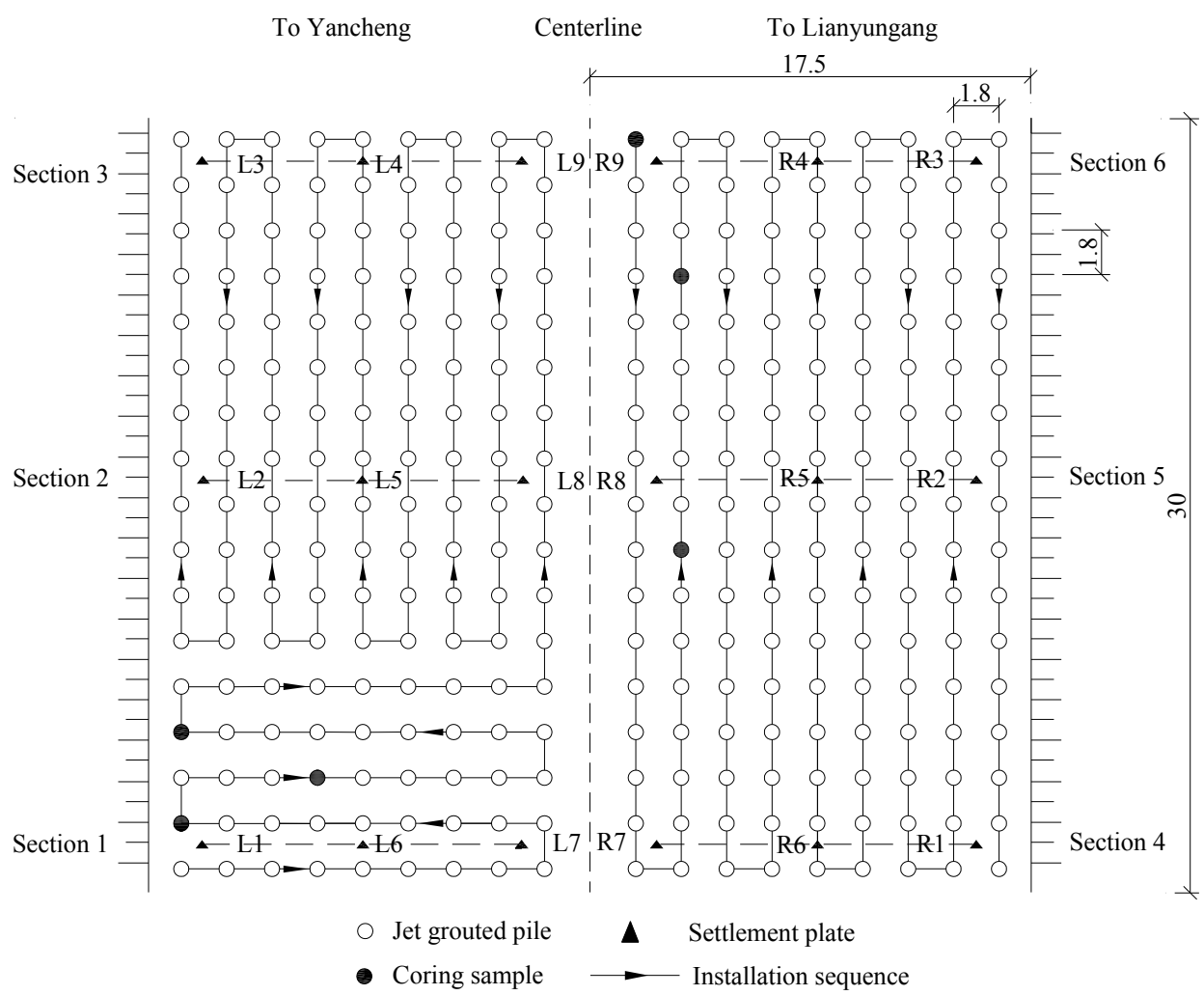

Fig. 3 Plan view of the experimental site on the Lianyan highway (unit: $\mathrm{m}$ ) 


\subsection{Field case of the Linhai highway}

The Linhai highway is $500 \mathrm{~km}$ long and connects Lianyungang, Yancheng, and Nantong in Jiangsu Province, China. The field trial on the Linhai highway was located in Lianyungang where the highway was subject to severe post-construction settlement. The technique was implemented to rehabilitate the highway. Before jet grouting, post-construction settlement had reached $90 \mathrm{~mm}$ at an average settling rate of $56 \mathrm{~mm} / \mathrm{y}$.

Ground investigations included a series of laboratory tests and a field exploration program. Water content and Atterberg limits were tested, and 1D consolidation tests and in-situ VSTs were carried out. The soil profile at this site is illustrated in Fig. 4. The improved zone can be divided into fill, clay, and silty clay layers, which were classified as $\mathrm{CL}, \mathrm{CH}$, and $\mathrm{CL}$, respectively, based on the unified soil classification system (ASTM, 2011). The fill forms the topmost 1.0-m-thick layer. The underlying clay layer extends to a depth of $10.4 \mathrm{~m}$. The groundwater table is located at a depth of $1.5 \mathrm{~m}$ below the ground surface. Table 3 summarizes the basic physical and mechanical properties of the soil. The clay layer has a relatively high void ratio and hence high compressibility, characteristics typical of the soft soil at this site. It is evident that the soil conditions are generally similar to those of the Lianyan highway.

A cross-section and a plan view of the experimental Linhai highway are presented in Figs. 4 and 5, respectively. The trial site was $50 \mathrm{~m}$ long and the embankment was $3.5 \mathrm{~m}$ high, with a crown width of $27.5 \mathrm{~m}$. The side slope $\mathrm{V}-\mathrm{H}$ (V, vertical; $\mathrm{H}$,

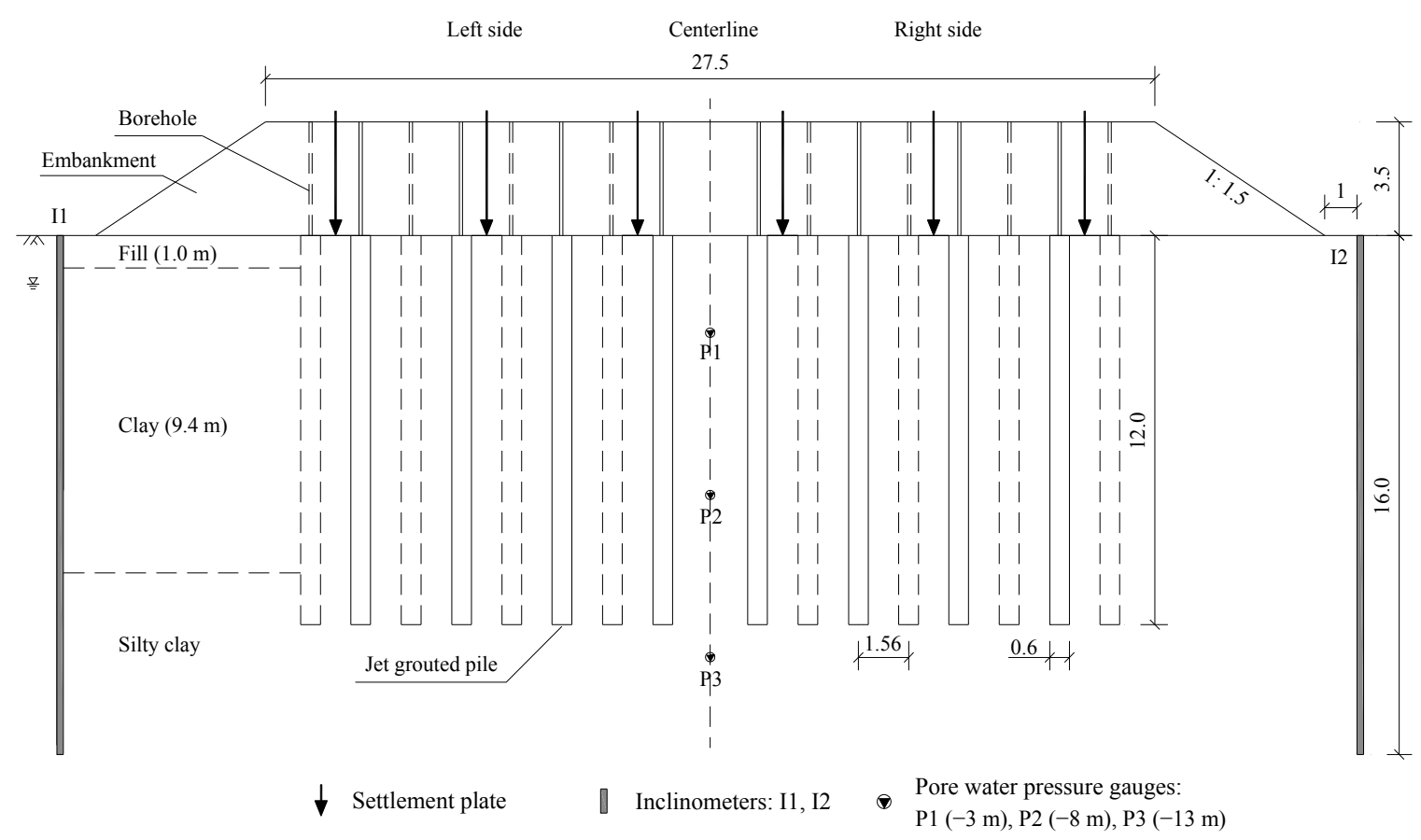

Fig. 4 Cross-section of the experimental site on the Linhai highway (unit: m)

Table 3 Main soil properties of the Linhai highway

\begin{tabular}{cccccccc}
\hline $\begin{array}{c}\text { Soil } \\
\text { profile }\end{array}$ & $\begin{array}{c}\text { Water } \\
\text { content, } w \\
(\%)\end{array}$ & $\begin{array}{c}\text { Liquid } \\
\text { limit, } w_{\mathrm{L}} \\
(\%)\end{array}$ & $\begin{array}{c}\text { Plastic } \\
\text { limit, } w_{\mathrm{P}} \\
(\%)\end{array}$ & $\begin{array}{c}\text { Void ratio, } \\
e\end{array}$ & $\begin{array}{c}\text { Total unit } \\
\text { weight, } \gamma \\
\left(\mathrm{kN} / \mathrm{m}^{3}\right)\end{array}$ & $\begin{array}{c}\text { Constrained } \\
\text { modulus, } E_{\mathrm{s}} \\
(\mathrm{MPa})\end{array}$ & $\begin{array}{c}\text { Undrained } \\
\text { shear strength, } \\
c_{\mathrm{u}}(\mathrm{kPa})\end{array}$ \\
\hline Fill & 28.7 & 34.5 & 19.8 & 0.98 & 17.8 & 3.02 & 16.5 \\
Clay & 48.6 & 51.3 & 23.6 & 1.12 & 17.2 & 2.71 & 15.4 \\
Silty clay & 38.7 & 44.2 & 25.1 & 0.78 & 19.6 & 4.34 & 23.6 \\
\hline
\end{tabular}


horizontal) ratio of the embankment was 1:1.5. The jet grouted piles were $12.0 \mathrm{~m}$ long and $0.6 \mathrm{~m}$ in diameter, and placed at $1.8 \mathrm{~m}$ spacings in a triangle grid. Each set of four piles in a line was installed in the transverse direction of the embankment and a total of 216 piles were implemented on each side (Fig. 5). The installation sequence of the piles is denoted by consecutive numbers.

Figs. 4 and 5 also show the detailed instrumentation on site, including settlement plates, inclinometers, and pore water pressure gauges. Nine settlement plates were embedded at the bottom of the embankment on each side. Two inclinometers (I1 and I2) each $16.0 \mathrm{~m}$ long were installed at a distance of $1.0 \mathrm{~m}$ from the toe of the embankment on both sides. Three pore water pressure gauges $(\mathrm{P} 1-\mathrm{P} 3)$ were mounted at the centerline of the embankment at depths of $-3,-8$, and $-13 \mathrm{~m}$, respectively. The grout pump pressure and drilling rod rotation rate used in this case were $22 \mathrm{MPa}$ and $23 \mathrm{r} / \mathrm{min}$, respectively. The other jetgrouting parameters were in line with those used in the Lianyan highway (Table 2). The pile installations on the left and right sides were completed successively during a $60-\mathrm{d}$ construction period. Core samples used for laboratory unconfined compression tests to evaluate pile quality indicated an average unconfined compression strength of $0.48 \mathrm{MPa}$.

\section{Results and discussion}

\subsection{Ground heave}

Fig. 6 shows the ground displacement profile measured on the Lianyan highway. All data were collected during the construction on each side. Note that Section 1 in Fig. 3 is not included because the settlement plate L6 was damaged during construction. Since grout slurry is injected into the ground at a high pressure during jet grouted piles construction, disturbance of the surrounding ground is inevitable, which will lead to significant ground movements. Several field cases where jet grouted piles were used for solidification of soft ground in basement excavation (Wong and Poh, 2000) or tunnelling (Wang et al., 2013) have been reported, indicating that large ground heaves can be induced during jet grouting. As expected, ground heave due to jet grouting was also observed in this study, implying that the embankment was uplifted. For each section, the heave profiles were generally similar. The measured heave at a distance of $8.75 \mathrm{~m}$ from the centerline was larger than that at a distance of $2.45 \mathrm{~m}$ and $15.05 \mathrm{~m}$. This is because the former heave was affected by more piles than the latter. For each side, heaves recorded at L5 $(219 \mathrm{~mm})$ and R5 $(213 \mathrm{~mm})$ located in the central zone were larger than others. This may be because in those

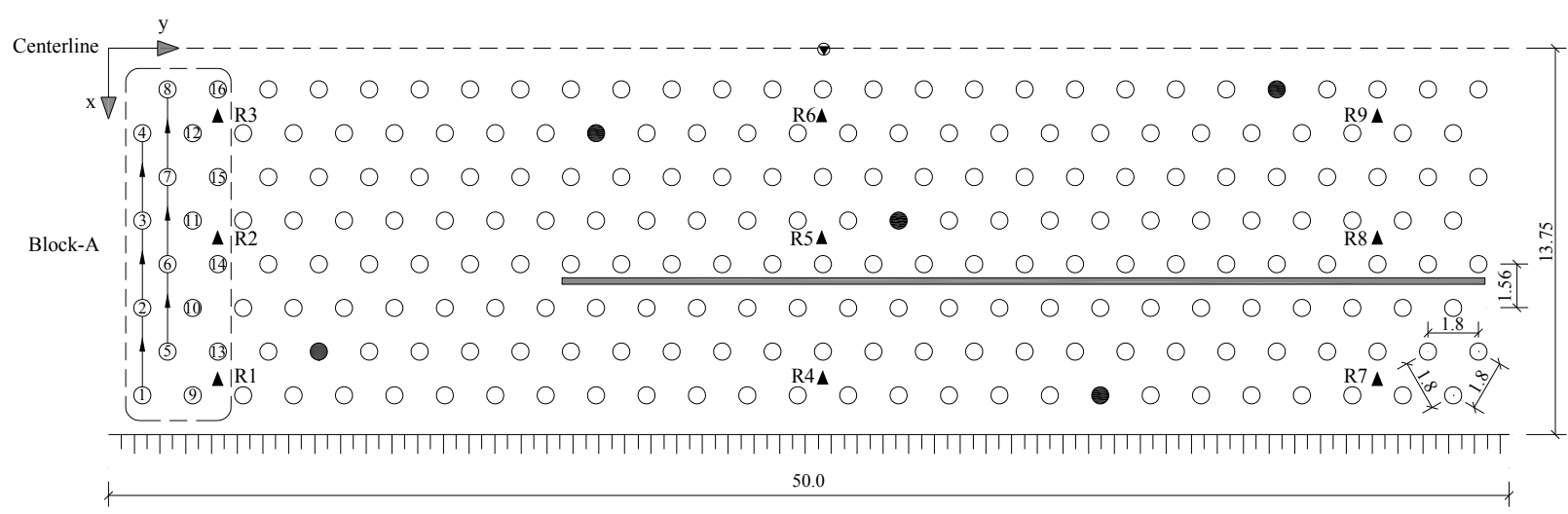

II2

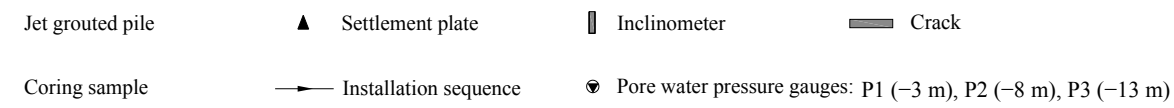

Fig. 5 Plan view of the experimental site on the Linhai highway (right side) (unit: $\mathrm{m}$ ) 

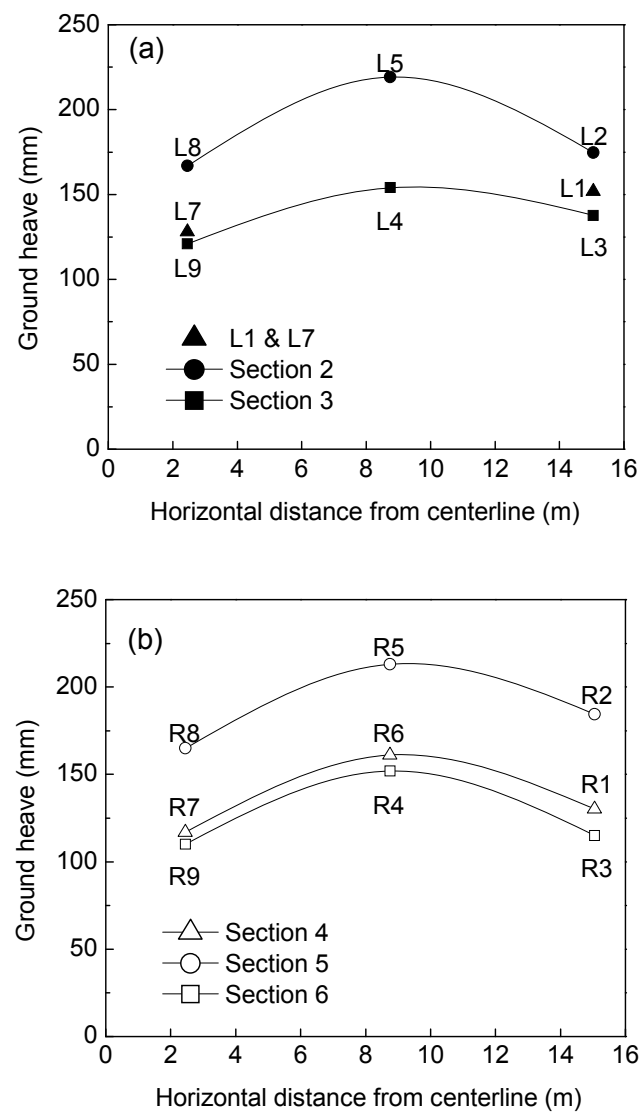

Fig. 6 Ground heave due to jet grouting on the Lianyan highway: (a) left side; (b) right side

specific locations the ground was greatly displaced by surrounding piles. For other plates placed close to the centerline and on the shoulder of embankment, the heaves varied between $110 \mathrm{~mm}$ at $\mathrm{R} 9$ and $184 \mathrm{~mm}$ at R2.

The variation in ground settlement with time on the Lianyan highway is presented in Fig. 7. For the abscissa, the time of origin is defined as when the construction of the highway was completed in 2006. Measurements at the bottom of the embankment showed a severe post-construction settlement of $420 \mathrm{~mm}$ before jet grouting caused by the high compressibility of soil (Table 1 ). The average settling rate was about $60 \mathrm{~mm} / \mathrm{y}$. The experiment using jet grouting began at the end of 2012 and finished in January 2013. During the 50-d construction period, a great heave of about $153 \mathrm{~mm}$ on average was induced by jet grouting. Considering the increased $233 \mathrm{~mm}$ thickness of the asphalt pavement, measurements from the surface of the embankment are also plotted.
The embankment was uplifted to offset the majority of the previous settlement. After jet grouting, the settling rate was markedly reduced to only $9 \mathrm{~mm} / \mathrm{y}$, suggesting that the technique could support the embankment and alleviate ground settlement significantly.

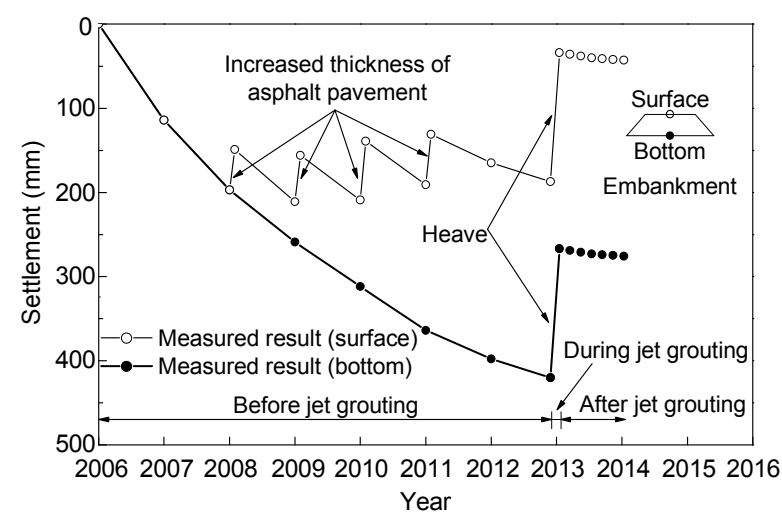

Fig. 7 Variation in ground settlement with time on the Lianyan highway

Fig. 8 shows a 3D view of the ground heave measured on the right side of the embankment on the Linhai highway. The definitions of the $x$-axis and $y$-axis are given in Fig. 5. Clearly, great heaves were generated by jet grouting to uplift the embankment. The maximum heave of $337 \mathrm{~mm}$ occurred at the middle settlement plate R5. The heave profiles appear to be of similar shape to those of the Lianyan highway (Fig. 6). However, a 33-m long crack, with a width of up to $224 \mathrm{~mm}$, extended along the longitudinal direction on the right side (Figs. 5 and 9). This may be explained by two reasons: first, the embankment may have been unable to sustain the overlarge heave resulting from the high grout pump pressure used at this site; second, there may have been fissures inside the embankment caused by the severe post-construction settlement before jet grouting was applied. To evaluate the practicality of the technique, follow-up field monitoring was conducted after jet grouting on the Linhai highway. This indicated that the settling rate was considerably reduced, from 56 to $7 \mathrm{~mm} / \mathrm{y}$.

From the results of the two field studies, although this technique performed well to mitigate the post-construction settlement of the operating highways, one issue is still of great concern during 
construction. Since jet grouting causes ground heave, it is vital to monitor the performance of the embankment to avoid overlarge heave and hence damage to the embankment. If necessary, the grout pump pressure could be adjusted reasonably during construction as it has the primary effect on the magnitude of ground heave.

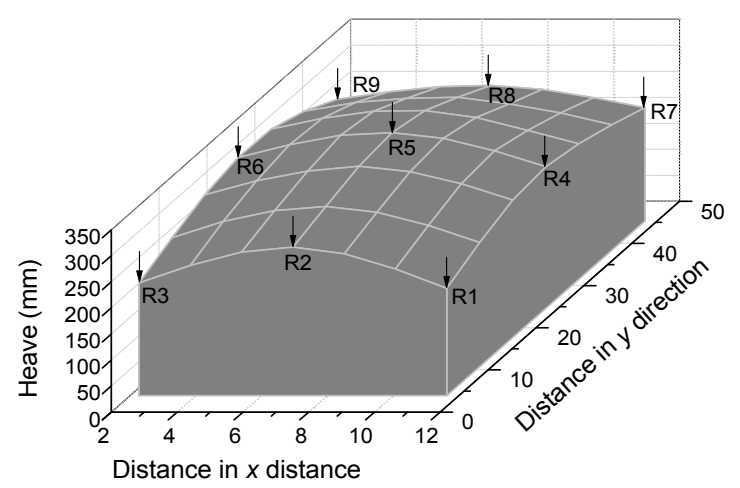

Fig. 8 A 3D view of ground heave measured on the Linhai highway

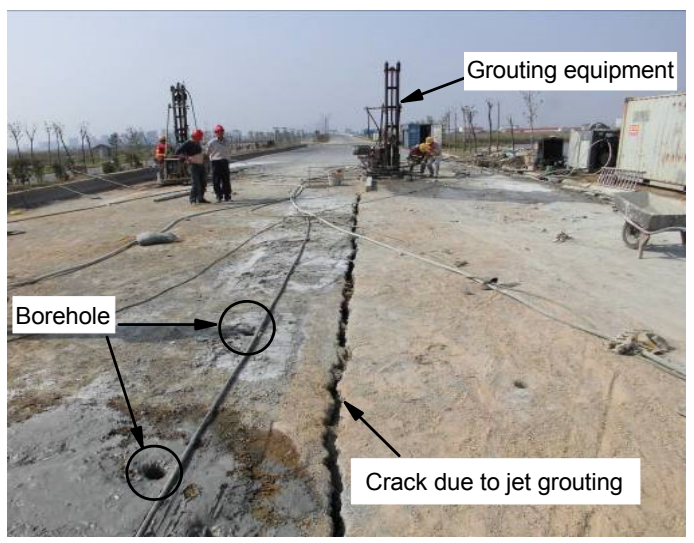

Fig. 9 Crack due to jet grouting on the Linhai highway

\subsection{Excess pore water pressure}

Fig. 10 shows the variation in pore water pressure measured at depths of $-3,-8$, and $-13 \mathrm{~m}$ with time since the start of jet grouting on the Linhai highway. The entire installation on both sides was completed in about $60 \mathrm{~d}$ with the installation of the left side carried out first. Excess pore water pressure increased greatly during the $60-\mathrm{d}$ construction period. The maximum excess pore water pressure measured was $64 \mathrm{kPa}$ at depth of $-8 \mathrm{~m}$, perhaps resulting from the expansion of surrounding soils due to the high grout pump pressure. The gauge P3 was placed beneath the pile tip and was therefore less affected by grout pump pressure than gauge $\mathrm{P} 2$ placed close to the mid-depth of the pile shaft. This may be why the excess pore water pressure increase at P3 was smaller than that at P2. After jet grouting, the excess pore water pressure dissipated gradually with time, suggesting that the influence on the surroundings was primarily during jet grouting.

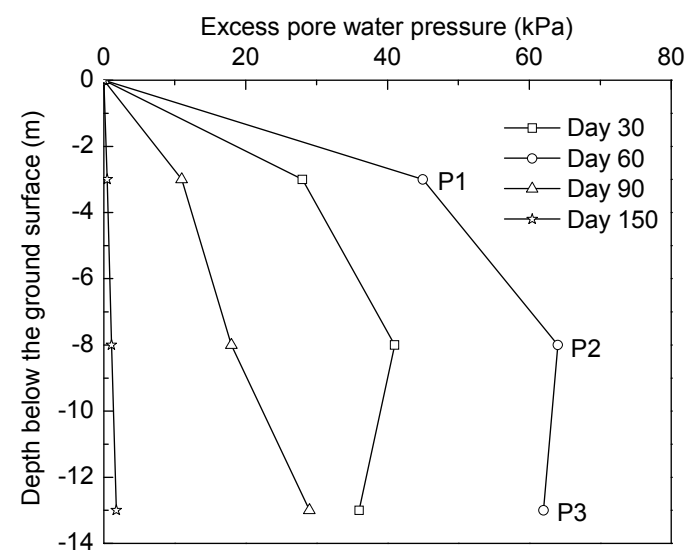

Fig. 10 Variation in excess pore water pressure with time on the Linhai highway

\subsection{Lateral displacement}

We expected that jet grouting would cause lateral ground displacement as well as ground heave. Fig. 11 depicts the lateral ground displacement profiles measured on the Linhai highway. For inclinometer I1 on the left side, it is clear that lateral displacement outwards from the embankment was induced in surrounding soils and increased during the 60-d construction period, within a maximum value of $49.5 \mathrm{~mm}$ at $-4 \mathrm{~m}$ depth. The displacement was mostly induced during the construction on the left side (i.e., from the beginning to the 30th day). Although the construction on the right side was in progress from day 30 to day 60 , the increase in ground displacement was very limited. This may have been due to the shadowing effect of the piles installed on the left side. Inclinometers I1 (left side) and I2 (right side) showed similar profiles. However, the maximum displacement measured by $\mathrm{I} 2(56.8 \mathrm{~mm})$ was larger than that of I1 $(49.5 \mathrm{~mm})$. This may have been caused by a 


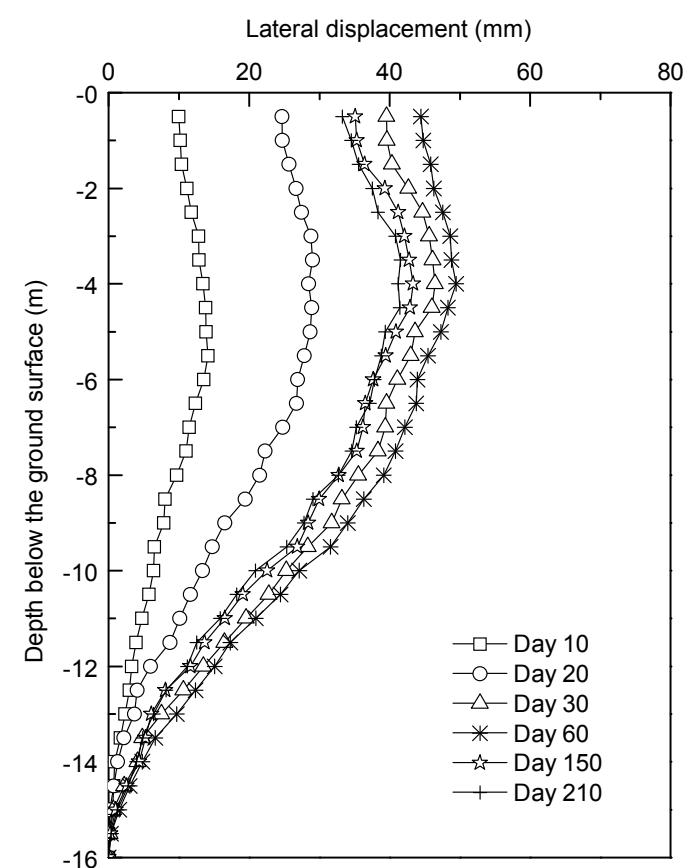

(a)

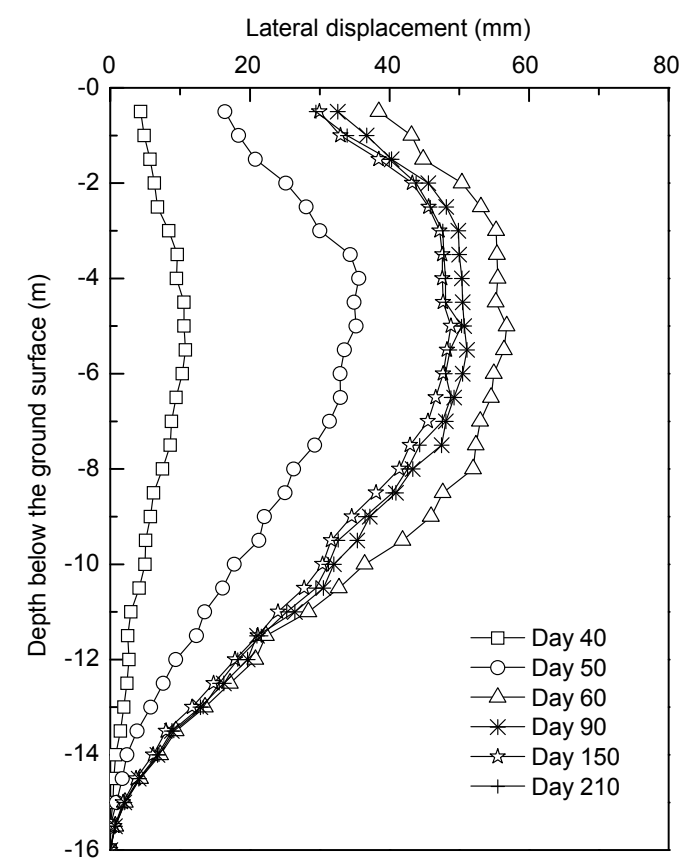

(b)

Fig. 11 Lateral ground displacement profiles on the Linhai highway

(a) Inclinometer I1; (b) Inclinometer I2

combination of construction sequence and the shadowing effect of piles, alleviating the disturbance on the left side caused by jet grouting on the right side. Note that the lateral displacement at day 90 and day 150 (i.e., 30 and $90 \mathrm{~d}$ after completion of construction) was markedly reduced. This may have been attributable to the dissipation of excess pore pressure (Fig. 10). The variation in lateral displacement became negligible after day 210.

\subsection{Relationship between ground heave and dis- tance from the pile center}

Based on cavity expansion theory, $\mathrm{Wu}$ et al. (2016) proposed an analytical method to study the response of a ground surface subjected to a single jet grouted pile as follows:

$$
\begin{aligned}
\delta= & \frac{3\left(1-v^{2}\right) d^{2}}{4 E}\left[\frac{Y+(\alpha-1) p}{3 \alpha}\right]^{\frac{3 \alpha}{2(\alpha-1)}} \\
& \times\left[\frac{2+\alpha}{Y+(\alpha-1) p_{0}}\right]^{\frac{\alpha+2}{2(\alpha-1)}}\left|\frac{1}{\sqrt{l^{2}+r^{2}}}-\frac{1}{r}\right|,
\end{aligned}
$$

where $\delta$ is the ground heave at the surface, $v$ is Poisson's ratio of soil, $E$ is Young's modulus of soil, $d$ is the pile diameter, $Y=2 c \cos \varphi /(1-\sin \varphi), \alpha=(1+\sin \varphi) /$ $(1-\sin \varphi), c$ is the soil cohesion, $\varphi$ is the soil friction angle, $p$ is the grout pump pressure, $p_{0}$ is the embankment load, $l$ is the pile length, and $r$ is the horizontal distance from the pile center.

Eq. (1) shows that the ground surface heave is dependent upon three variables for given parameters of the soil and pile: grout pump pressure $p$, embankment load $p_{0}$, and horizontal distance from the pile center $r$. Furthermore, the amount of ground heave decreases with a lower grout pump pressure, a larger embankment load, and increasing horizontal distance from pile center. As the grout pump pressure used during jet grouting is always much higher than the embankment load, the effect of the pump pressure on ground heave is more significant. The typical grout pump pressure used on the Lianyan highway was $20 \mathrm{MPa}$, whereas the pressure used on the Linhai highway reached $22 \mathrm{MPa}$, explaining why the ground heaves on the Linhai highway were relatively large.

To further investigate the relationship between ground heave and horizontal distance from the pile center, the results from the settlement plate $\mathrm{R} 2$ are shown in Fig. 12. The heave was measured after each 
adjacent pile P1-P16 in Block-A was completed (Fig. 5). The corresponding analytical result obtained from the above solution is also included for comparison. For simplicity, the soil parameters used in the analytical result were determined by the soil properties typical of the clay (Table 4). Note that Young's modulus of clay was taken as $E=400 c_{\mathrm{u}}$, as suggested by Poulos and Davis (1980). The average unit weight of the embankment fill was $20 \mathrm{kN} / \mathrm{m}^{3}$. Considering that jet grouted pile is composed of injected grout and soil, an equivalent pile diameter $d^{*}$ was taken as about 0.4 times the nominal pile diameter $d$, as discussed by Weng (2006). The horizontal distances between R2 and each pile P1-P16 can be calculated by geometry (Fig. 5). In Fig. 12, both the ground heave and distance from the pile center are normalized with respect to the nominal pile diameter $d$. The analytical result is larger than the measured result. This difference may have arisen because the effects of other piles within the group were not considered in this study.

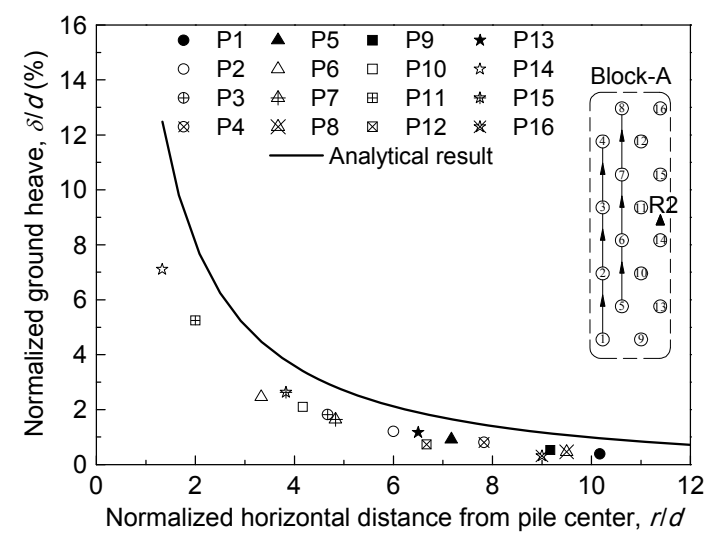

Fig. 12 Relationship between normalized ground heave and horizontal distance from the pile center

Table 4 Basic parameters used in the analytical result

\begin{tabular}{cc}
\hline Parameter & Value \\
\hline$c(\mathrm{kPa})$ & 15 \\
$\varphi\left({ }^{\circ}\right)$ & 20 \\
$E(\mathrm{MPa})$ & 6.1 \\
$v$ & 0.4 \\
$p(\mathrm{MPa})$ & 22 \\
$p_{0}(\mathrm{kPa})$ & 70 \\
$l(\mathrm{~m})$ & 12 \\
$d^{*}(\mathrm{~m})$ & 0.24 \\
\hline
\end{tabular}

Nevertheless, the measured result implies that the induced ground heave decreased with increasing distance from the pile center, which is consistent with the analytical result.

\section{Conclusions}

In this paper, a technique using jet grouted piles is proposed to address the issue of severe postconstruction settlement in operating highways. Two field studies of the application of the technique to operating highways over soft ground in China are presented. The following conclusions can be drawn:

1. Ground heave with a maximum value of $219 \mathrm{~mm}$ was induced over a short construction period on the Lianyan highway. The uplift of the embankment was sufficient to offset most of the previous settlement. Long-term field results showed that the average settling rate was reduced significantly, from $60 \mathrm{~mm} / \mathrm{y}$ before construction to $9 \mathrm{~mm} / \mathrm{y}$ after construction, suggesting that the technique could be effective in supporting the embankment and mitigating ground settlement of operating highways in China.

2. Based on the adopted analytical method, ground heave due to a single jet grouted pile was found to depend mainly on grout pump pressure, embankment load, and horizontal distance from the pile center. Moreover, both the measured and analytical results revealed that the ground heave decreased with increasing distance from the pile center.

3. A larger maximum ground heave of $337 \mathrm{~mm}$ was measured on the Linhai highway than that on the Lianyan highway. This is because the increase in grout pump pressure had a significant effect on the induced heave, as indicated by the analytical method. Owing to the great heave, cracking occurred along the longitudinal direction of the embankment during construction. Both excess pore water pressure and lateral ground displacement were also caused by jet grouting on the Linhai highway. The maximum excess pore water pressure observed was $64 \mathrm{kPa}$, near the mid-depth of the pile shaft at the end of construction. The lateral displacement increased to as much as $56.8 \mathrm{~mm}$ during construction, but appeared to reduce after construction, in association with the dissipation of excess pore water pressure. 


\section{References}

ASTM (American Society for Testing and Materials), 2011. Standard Practice for Classification of Soils for Engineering Purposes (Unified Soil Classification System), ASTM Standard D2487. ASTM, West Conshohocken, PA, USA.

Chang, S.B., Zhang, S.M., 2007. Manual of Engineering Geology. China Building Industry Press, Beijing, China, p.158-162 (in Chinese).

Chu, J., Yan, S.W., Yang, H., 2000. Soil improvement by the vacuum preloading method for an oil storage station. Géotechnique, 50(6):625-632.

http://dx.doi.org/10.1680/geot.2000.50.6.625

Deng, Y.F., Yue, X.B., Cui, Y.J., et al., 2014. Effect of pore water chemistry on the hydro-mechanical behaviour of Lianyungang soft marine clay. Applied Clay Science, 95:167-175

http://dx.doi.org/10.1016/j.clay.2014.04.007

Flora, A., Modoni, G., Lirer, S., et al., 2013. The diameter of single, double and triple fluid jet grouting columns: prediction method and field trial results. Géotechnique, 63(11):934-945. http://dx.doi.org/10.1680/geot.12.P.062

Hanna, A.M., Yulek, M., 2014. Impact compaction on a subgrade layer overlying deep deposit. International Journal of Pavement Engineering, 15(8):742-751. http://dx.doi.org/10.1080/10298436.2013.857777

Liu, H.L., Kong, G.Q., Chu, J., et al., 2015. Grouted gravel column-supported highway embankment over soft clay: case study. Canadian Geotechnical Journal, 52(11): 1725-1733.

http://dx.doi.org/10.1139/cgj-2014-0284

Mayne, P.W., Jones, J.S.Jr., Dumas, J.C., 1984. Ground response to dynamic compaction. Journal of Geotechnical Engineering, 110(6):757-774. http://dx.doi.org/10.1061/(asce)0733-9410(1984)110:6(757)

Modoni, G., Bzówka, J., 2012. Analysis of foundations reinforced with jet grouting. Journal of Geotechnical and Geoenvironmental Engineering, 138(12):1442-1454. http://dx.doi.org/10.1061/(asce)gt.1943-5606.0000718

Poh, T.Y., Wong, I.H., 2001. A field trial of jet-grouting in marine clay. Canadian Geotechnical Journal, 38(2): 338-348. http://dx.doi.org/10.1139/t00-093

Poulos, H.G., 2007. Design charts for piles supporting embankments on soft clay. Journal of Geotechnical and Geoenvironmental Engineering, 133(5):493-501. http://dx.doi.org/10.1061/(asce)1090-0241(2007)133:5(493)

Poulos, H.G., Davis, E.H., 1980. Pile Foundation Analysis and Design. Wiley, New York, USA.

Saowapakpiboon, J., Bergado, D.T., Voottipruex, P., et al., 2011. PVD improvement combined with surcharge and vacuum preloading including simulations. Geotextiles and Geomembranes, 29(1):74-82.

http://dx.doi.org/10.1016/j.geotexmem.2010.06.008

Schaefer, V.R., Mitchell, J.K., Berg, R.R., et al., 2012. Ground improvement in the 21st century: a comprehensive web-based information system. Geotechnical Engineering State of the Art and Practice: Keynote Lectures from GeoCongress 2012, Oakland, California, USA. American Society of Civil Engineers (ASCE), USA, p.272-293. http://dx.doi.org/10.1061/9780784412138.0011

Shahu, J.T., Reddy, Y.R., 2011. Clayey soil reinforced with stone column group: model tests and analyses. Journal of Geotechnical and Geoenvironmental Engineering, 137(12):1265-1274.

http://dx.doi.org/10.1061/(asce)gt.1943-5606.0000552

van Paassen, L.A., Ghose, R., van der Linden, T.J.M., et al., 2010. Quantifying biomediated ground improvement by ureolysis: large-scale biogrout experiment. Journal of Geotechnical and Geoenvironmental Engineering, 136(12):1721-1728. http://dx.doi.org/10.1061/(asce)gt.1943-5606.0000382

Wang, Z.F., Shen, S.L., Ho, C.E., et al., 2013. Investigation of field-installation effects of horizontal twin-jet grouting in Shanghai soft soil deposits. Canadian Geotechnical Journal, 50(3):288-297. http://dx.doi.org/10.1139/cgj-2012-0199

Weng, C.X., 2006. Study on a Subway Shield Tunnel under the Excess Pore Pressure by High-pressure Jet Grouting. MS Thesis, Tongji University, Shanghai, China (in Chinese).

Wong, I., Poh, T., 2000. Effects of jet grouting on adjacent ground and structures. Journal of Geotechnical and Geoenvironmental Engineering, 126(3):247-256. http://dx.doi.org/10.1061/(asce)1090-0241(2000)126:3(247)

Wu, Y.D., Diao, H.G., Ng, C.C.W., et al., 2016. Investigation of ground heave due to jet grouting in soft clay. Journal of Performance of Constructed Facilities, 06016003. http://dx.doi.org/10.1061/(asce)cf.1943-5509.0000910

Ye, G.B., Zhang, Z., Han, J., et al., 2013. Performance evaluation of an embankment on soft soil improved by deep mixed columns and prefabricated vertical drains. Journal of Performance of Constructed Facilities, 27(5):614-623. http://dx.doi.org/10.1061/(asce)cf.1943-5509.0000369

Yoshitake, I., Nakagawa, K., Mitsui, T., et al., 2004. An evaluation method of ground improvement by jet grouting. Tunnelling and Underground Space Technology, 19(4-5):496-497. http://dx.doi.org/10.1016/j.tust.2004.02.094

Zhou, W.H., Chen, R.P., Zhao, L.S., et al., 2012. A semianalytical method for the analysis of pile-supported embankments. Journal of Zhejiang University-SCIENCE A (Applied Physics \& Engineering), 13(11):888-894. http://dx.doi.org/10.1631/jzus.A12ISGT4 


\section{中文概要}

\section{题 目：既有高速公路沉降处治技术现场试验研究}

目 的：集成路堤坚向小直径引孔高压旋喷桩技术的施工 工艺, 分析其对既有高速公路沉降病害的处治效 果, 研究路堤在施工过程中的变形特性。

创新点：提出路堤坚向小直径引孔高压旋喷桩技术, 并通 过现场试验和理论研究分析其对既有高速公路 沉降的处治效果。

方 法：1. 通过两组现场试验, 对处治前后路堤坚向变形 （图 6 8）、地基内超孔隙水压力（图 10）和深 层土体水平位移 (图 11) 的变化特性进行分析与 研究; 2. 引用 Wu et al. (2016)的理论解答（公式
1) 构建单桩引起的路堤隆起变形与路堤荷载和 注浆压力之间的关系, 为工艺参数调节提供依 据, 并利用实测数据加以验证。

结 论：1. 坚向小直径引孔高压旋喷桩技术能够在较短的 时间内抬升路堤和加固地基, 从而有效降低既有 高速公路的工后沉降速率, 处治效果明显。2. 路 堤隆起变形的大小主要与路堤荷载和注浆压力 有关, 且随着与桩中心距离的增大而减小; 通过 合理调节注浆压力可以防止路堤因隆起过大而 发生破坏。3. 施工期内, 高压旋喷会导致超孔隙 水压力和深层土体水平位移显著增大; 随后, 超 孔隙水压力逐渐消散, 深层土体水平位移也发生 一定的回弹。

关键词：既有高速公路; 工后沉降; 旋喷桩; 土体隆起 